\title{
PENGARUH WORKPLACE WELL-BEING TERHADAP KINERJA GURU SD
}

\author{
Herwanto* \\ Fitrah Tul Ummi** \\ *Fakultas Pendidikan Psikologi, Universitas Negeri Jakarta \\ ** Fakultas Pendidikan Psikologi, Universitas Negeri Jakarta
}

DOI: https://doi.org/10.21009/JPPP.061.07

\author{
Alamat Korespondensi: \\ herwanto.psi@gmail.com
}

\begin{abstract}
Teacher performance is teacher perception on teacher work performance related to work quality, responsibility, honesty, cooperation and initiative. This study was conducted to obtain empirical evidence of the effect of good work on the performance of elementary school teachers in central Jakarta. This research uses quantitative approach. A sample of 79 certified teachers teaching elementary school in central Jakarta using multiphase sampling technique. How to use data by using questionnaire media for data retrieval. Respondents of this study are teachers of primary school certified in central Jakarta. The variable used is workplace wellbeing as independent variable, teacher performance as dependent variable. To determine the effect of workplace well-being, based on multiple regression analysis at $33.1 \%$ significant level it can be concluded whether the workplace well-being is significant enough to the performance of elementary school teachers.
\end{abstract}

\section{Keywords}

workplace well-being, performance, teacher

\section{Pendahuluan}

Kinerja guru adalah komponen penting dalam peningkatan pendidikan yang akan berimbas pada kualitas sumber daya manusia. Sumber daya manusia yang berkualitas di masa depan terhadap penguasaan ilmu pengetahuan dan teknologi membutuhkan penyelenggaraan pendidikan yang bermutu pada setiap jenjang pendidikan, oleh sebab itu, diperlukan peningkatan kemampuan tenaga pendidikan (Pratiwi, 2013).

Guru merupakan seorang figur utama yang memegang peran penting dalam membangun pendidikan formal di sekolah. Keberhasilan peserta didik dalam proses belajar mengajar merupakan penentu pendidikan yang berkualitas, maka agar meningkatnya kualitas pendidikan tidak akan signifikan tanpa didukung oleh guru yang profesional dan berkualitas (Wardana, 2013).
Guru sebagai pendidik profesional memiliki tugas utama mendidik, mengajar, membimbing, mengarahkan, melatih, menilai dan mengevaluasi peserta didik dalam pendidikan anak usia dini jalur pendidikan formal, pendidikan dasar, dan pendidikan menengah. Dalam melaksanakan tugas tersebut, guru menerapkan keahlian dan kemahirannya dalam memenuhi standar mutu atau norma tertentu yang diperoleh melalui pendidikan profesi. Pengakuan kedudukan guru sebagai tenaga profesional dibuktikan dengan cara melakukan sertifikasi bagi guru dalam jabatan (Jaedun, 2009).

Menurut Didi Atmadilaga (dalam Rusman, 2010) profesi merupakan wewenang praktik suatukejuruan yang bersifat pelayanan pada kemanusiaan secara intelektual spesifik yang sangat tinggi yang didukung oleh pengguasaan pengetahuan keahlian serta seperangkat sikap dan kete- 
rampilan teknik yang diperoleh melalui pendidikan dan latihan khusus yang penyelenggaraannya dilimpahkan kepada lembaga pendidikan tinggi yang bersama memberikan izin praktik atau penolakan praktik dan kelayakan praktik yang dilindungi oleh peraturan perundangundangan yang berlaku, baik yang diawasi langsung oleh pemerintah maupun asosiasi profesi yang bersangkutan.

Profesi seorang guru merupakan suatu keahlian dalam bidang tertentu yang mensyaratkan kompetensi intelektual, sikap dan keterampilan yang diperoleh melalui proses pendidikan secara akademik yang intensif, tetapi masih banyak guru yang belum mengoptimalkan profesi tersebut dengan baik, seperti hasil survey yang dilakukan oleh Persatuan Guru Republik Indonesia (PGRI) tahun 2009 mengenai dampak sertifikasi profesi terhadap kinerja guru, dari 16 sampai 28 provinsi yang telah diteliti dapat dikatakan bahwa kinerja guru masih belum meningkat secara signifikan, padahal seorang guru mestinya terus membangun citra guru mulai dengan bekerja bersungguhsungguh dalam meningkatkan kualitas diri danmenjadi teladan (Sulistiyo, Anggota Dewan Perwakilan Daerah, 2009).

Kinerja guru adalah kemampuan atau keahlian seorang guru dalam melaksanakan tujuan yang telah ditetapkan. Menurut Depdiknas (2010) kinerja guru dilakukan terhadap tiga tahap meliputi aspek perencanaan mengajar, pelaksanaan mengajar dan evaluasi hasil belajar.Di Indonesia kinerja guru saat ini sangat mengkhawatirkan dari hasil wawancara yang dilakukan pada tanggal 20 Mei 2017 mengenai proses belajar mengajar ternyata masih banyak ditemukan guru-guru dalam proses pembuatan perencanaan pembelajaran mengikuti rencana pembelajaran orang lain, seharusnya rencana pelaksanaan pembelajaran dibuat oleh guru itu sendiri supaya sesuai dengan karakteristik dan kebutuhan peserta didiknya. Dalam aspek pembelajaran juga ditemukan guru-guru yang belum disiplin dalam bekerja seperti: terlambat memasuki kelas dan mengakhiri kegiatan belajar mengajar lebih dahulu sebelum bel dibunyikan. Selain itu masih banyak guru yang tidak kreatif dalam menyusun strategi pembelajaran yang afektif dan menciptakan media pembelajaran yang menarik, tepat, dan jelas untuk peserta didik. Dalam metode pembelajaran yang guru ajarakan masih ditemukan guru yang berbicara didepankelas dibandingkan menggunakan metode pembelajaran yang lain. Evaluasi pembelajaranyang dilakukan oleh guru masih banyak menggunakan sistem evaluasi dengan tes tertulis dibandingkan sistem evaluasi pembelajaran lain. Seharusnya guru bisa memilih menggunakan sistem evaluasi pembelajaran yang sesuai dengan kebutuhan peserta didik dan materi pembelajaran yang sedang dipelajari.

Menurut Undang-Undang No.20 Tahun 2003 tentang Sisdiknas, pasal 3 yang berbunyi Pendidikan Nasional berfungsi mengembangkan kemampuan dan membentuk watak serta peradaban bangsa yang bermartabat dalam rangka mencerdasakan kehidupan bangsa, bertujuan untuk perkembangan potensi peserta didik menjadi manusia yang beriman, bertaqwa kepada Tuhan Yang Maha Esa, berakhlak mulia, sehat, berilmu, cakap, kreatif, mandiri, dan menjadi warga negara yang demokratis serta bertanggung jawab. Oleh sebab itu, Pendidikan Nasional, merupakan pendidikan tidak hanya bertujuan untuk mencerdasakan kehidupan bangsa akan tetapi juga membentuk watak dan kepribadian peserta didik.

Memiliki kinerja yang berkualitas merupakan hal yang tidak mudah, karena banyak syaratsyarat yang harus dipenuhi oleh seorang guru untuk dapat menjadi guru profesional dengan kinerja yang berkualitas. Menurut Bahri, (2011) mengatakan kinerja yang dimiliki setiap guru berbeda-beda dengan guru lainnya. Perbedaan tersebut adanya perbedaan karakteristis pada masing-masing individu. Guru yang memiliki keinginan untuk berprestasi akan menghasilkan kinerja yang optimal. Sebaliknya, guru yang tidak memilikikeinginan untuk berprestasi cenderung menghasilkan kinerja yang rendah. Kinerja guru akan menjadi optimal, jika diintegrasikan dengan komponen-komponen yang mempengaruhi kinerja guru seperti workplace well-being guru.

Pada penelitian sebelumnya yang dilakukan oleh Muhammad Jibril Alfarisi pada tahun 2016 mengenai pengaruh workplace well-being terhadap kinerja karyawan Staff di PT.X. Dengan hasil penelitian menemukan bahwa adanya pengaruh yang signifikan terhadap kinerja karyawan di PT.X. Dalam penelitian ini peneliti 
menggunakan variabel workplace well-being terhadap kinerja guru di sekolah dasar.

Workplace well-being atau kesejahteraan ditempat kerja adalah perasaan sejahtera yang dirasakan oleh para pekerja terhadap tempat kerjanya. Konsep workpace well-being adalah komponen aplikasi dari subjektive well-being. Subjective well-being adalah kondisi pikiran yang positif yang melibatkan seluruh pengalaman hidup. Komponen subjective well-being mencakup kepuasan hidup, afeksi positif dan afeksi negatif (Diener et al, suh, lucas, \& Smith dalam Page, 2005). Kondisi pikiran yang positif dan penilaian positif dari seorang guru serta hubungan yang terjalin baik dengan rekan kerja akan mempengaruhi perfoma kerja dan kualitas hidup guru tersebut. Menurut Warr (2009) workplace well-being merupakan suatu kewajiban: banyak orang percaya bahwa memperbaiki workplace well-being akan memberikan dampak yang positif bagi performa sekolah secara keseluruhan.

Menurut Pryce-Jones (dalam Chen, 2014) workplace well-being dapat membentuk pikiran seseorang ke arah memaksimumkan prestasi kerja dan mencapai potensi diri. Dalam konteks sekolah, workplace well-being diharapkan dapat meningkatkan prestasi guru melalui tingkat inovatif dan komitmen afektif guru. Sifat-sifat kecermelangan guru turut dapat memperngaruhi keseluruhan organisasi secara kolektif. Hal ini merupakan karena workplace well-being dapat mempengaruhi dan memberi semangat kepada rekan setugas disekitarnya.

Lingkungan kerja merupakan salah satu faktor well-being setiap guru yang harus diperhatikan karena faktor tersebut berperan dalam bentuk presepsi guru terhadap pekerjaanya yang sedang dijalani dan presepsi guru terhadap workplace. Menurut Suojanen, (dalam Wulandari \& Ami, 2014). Aspek-aspek workplace well-being antara lain gaji, jam kerja, rekan kerja, lingkungan kerja, manajemen, kepribadian dan sikap. Selain itu, nilai pekerjaan memiliki dampak yang besar pada kebahagiaan individu di tempat kerja

Pemberian tunjangan sertifikasi bagi guru sebagaimana yang telah disebutkan dalam Undang-undang No.14 Tahun 2005 tentang Guru dan Dosen, hal tersebut termasuk kebijakan pemerintah yang di dalamnya memuat usaha menata dan memperbaiki kinerja guru. Dengan begitu, makapemerintah dan pihak sekolah harus memperhatikan lebih cermat lagi terhadap faktor kinerja guru dalam halnya well-being guru dalam lingkungan kerja dan pemberian upah atau gaji dengan hak dan tanggung jawab guru sesuai dengan kinerjanya supaya tujuan pendidikan untuk menciptakan sumber daya manusia yang berpotensi dan berkualitas dapat tercapai dengan baik dan maksimal. Intinya individu yang workplace well-being akan berdampak positif dan negative bagi instansi. dengan melihat yang didapatkan dari individu dalam bekerja. Namun untuk meningkatkan kesejahteraan individu dalam bekerja, penting untuk terlebih dahulu mengetahui faktor workplace well-being pada guru.

Workplace well-being menurut Page (2005) artinya rasa sejahtera yang diperoleh pekerja dari pekerjaan mereka yang berkaitan dengan perasaan pekerja secara umum (coreaffect), dan nilai intrinsik dan ekstrinsik dari pekerjaan (work value). Core affect adalah sebagai suatu keadaan dimana rasa nyaman dan tidak nyaman bercampur gairah (passion) yang mempengaruhi aktivitas manusia (Russel dalam Page, 2005). Sedangkan work value menekankan pada nilai intinsik dan ekstrinsik sebagai derajat harga, kepentingan, dan hal-hal yang disukai oleh individu di tempat kerja. (Knoop dalam Page, 2005).

\section{Metode Penelitian}

Tipe penelitian yang digunakan dalam penelitian ini adalah peneltian guru di sekolah. Subjek penelitian ini memiliki karakteristik sebagai berikut, berdomisis di Jakarta pusat, usia dari 25-60 tahun, pendidikan S1-S2. Teknik sampling yang dilakukan dalam penelitian ini adalah probabilitas sampling. Teknik yang digunakan adalah jenis multiphase atau double sampling. Jumlah sampel dalam penelitian ini adalah sebanyak 79 orang.

Pada penelitian ini, pengumpulan data dilakukan dengan menggunakan kuesioner sebagai alat pengumpulan data. Kuesioner untuk variabel workplace well-being terhadap kinerja guru menggunakan alat ukur workplace well-being dikembangkan oleh Page pada tahun 2005. Instrumen ini berjumlah 19 pertanyaan. Instrumen kinerja guru yang dikembangkan dari penelitian Victy Vidaya Viqraizin 2015. Instrumen ini berjumlah 38 pertanyaan. 


\section{Hasil Penelitian dan Diskusi}

Dari perhitungan data variabel workplace wellbeing dan kinerjaguru diperoleh nilai rata-rata dannilai simpangan baku tiap variabel. Adapun nilai tersebut yaitu: nilai rata-rata workplace wellbeing 1,64 dan kinerja guru 0,52. nilai deviasi standar atau simpangan baku workplace well- being sebesar 0,759 sedangkan nilai standar deviasi kinerja guru sebesar 1,102. Dengan mengetahui besarnya nilai rata-rata (mean) dan deviasi standar maka dapat diketahui tingkat workplace well-being dan kinerja guru sebagai berikut:

Tabel 1. Kategorisasi Skor Workplace Well-Being

\begin{tabular}{ccc}
\hline Kategori & Frekuensi & Persentasi \\
\hline Rendah & 49 & $62 \%$ \\
\hline Tinggi & $30 \%$ & $38 \%$ \\
\hline Total & $\mathbf{7 9}$ & $\mathbf{1 0 0 \%}$ \\
\hline
\end{tabular}

Tabel 2. Kategorisasi Skor Kinerja

\begin{tabular}{ccc}
\hline Kategori & Frekuensi & Persentasi \\
\hline Rendah & 43 & $54,4 \%$ \\
\hline Tinggi & 36 & $45,6 \%$ \\
\hline Total & $\mathbf{7 9}$ & $\mathbf{1 0 0 \%}$
\end{tabular}

Dari Tabel 1 di atas dapat diketahui bahwa workplace well-being dari responden dalam penelitian ini yang didominasi oleh responden yang workplace well-being rendah sebesar $62 \%$ dan $38 \%$ dengan workplace well-being yang tinggi.
Sedangkan pada Tabel 2 variabel kinerja guru didominasi oleh responden penelitian yang memiliki kinerja yang rendah yaitu sebesar $54,4 \%$ dan $45.6 \%$ dengan kinerja yang tinggi.

Untuk mengetahui besarnya pengaruh workplace well-being terhadap kinerja guru dapat dilihat pada Tabel 3 di bawah ini.

Tabel 3. Persamaan Regresi

\begin{tabular}{lcc}
\hline Pearson Correlation & $\begin{array}{c}\text { Sig. } \\
\text { (1-tailed) }\end{array}$ & B \\
\hline $\begin{array}{l}\text { Workplace Well- } \\
\text { Being-Kinrja Guru }\end{array}$ & 0,001 & $-0,855$ \\
\hline
\end{tabular}

Berdasarkan hasil perhitungan di atas maka didapatkan koefisien korelasi variabel workplace well-being dengan kinerja guru sebesar $-0,855$ dan sig. sebesar 0,001 . Nilai probabilitas atau sig. sebesar 0,001 yaitu lebih kecil dari tingkat kesalahan sebesar 0,05. Hal ini diartikan bahwa terdapat pengaruh yang signifikan antara workplace well-being terhadap kinerja guru SD.

Koefisien korelasi variabel workplace wellbeing terhadap kinerja guru sebesar -0,855. Arah korelasi yang negatif mengandung arti bahwa semakin rendah workpace well-being guru maka semakin rendah kinerja guru, sebaliknya semakin tinggi workplace well-being guru maka akan semakin tinggi kinerja guru.

Nilai koefisien determinansi (R Square) adalah 0,331 yang berarti pengaruh workplace wellbeing terhadap kinerja guru sebesar $33,1 \%$ sedangkan $66,9 \%$ kinerja guru dipengaruhi oleh variabel lain selain workplace well-being.

Berdasarkan hasil analisis dapat peneliti jelaskan bahwa kinerja guru mempunyai peran yang penting dalam meningkatkan potensi dan kualitas peserta didik. Keberhasilan peserta didik dimasa depan dalam penguasaan pengetahuan dan teknologi merupakan penentu pendidikan yang berkualitas. Hal tersebut perlunya pening- 
katan pada kinerja guru secara optimal untuk itu guru perlu memperhatikan aspek-aspek yang dapat mempengaruhi kinerja guru yang berkaitan dengan peningkatan kinerja guru disekolah. Dalam penelitian ini lingkungan kerja guru merupakan salah satu faktor yang mempengaruhi kinerja guru.

Dari hasil analisis data dapat diketahui bahwa dari 79 guru 54,4\% (43) guru memiliki kinerja yang masih rendah sedangkan 45,6\% (36) guru memiliki kinerja yang tinggi, hal tersebut sesuai dari hasil wawancara tidak berstruktur peran guru dalam proses belajar mengajar masih ditemukan guru-guru yang belum optimal dalam menggunakan kemampuannya seperti masih mengikuti proses membelajaran orang lain, dalam disiplin waktu masih banyak yang terlambat memasuki kelas dan mengakhiri waktu belajar lebih dahulu sebelum bel berbunyi, masih banyak guru dalam menyampaikan materi hanya berbicara di depan kelas dan dalam melakukan evaluasi belajar masih banyak guru yang menggunakan evaluasi tes tertulis.

Sedangkan hasil analisis deskriptif dari workplace well-being terhadap kinerja guru dapat diketahui bahwa workplace well-being guru masih rendah. Diketahui dari hasil statistik bahwa dari jumlah 79 guru 62\% (49) guru memiliki workplace well-being rendah terhadap lingkungan kerjanya sedangkan $38 \%$ (30) memiliki workplace well-being tinggi terhadap lingkungan kerjanya. Padahal jika dilihat dari hasil $\mathrm{R}$ square workplace well-being memiliki pengaruh sebesar 0,331 . Hal ini menunjukkan bahwa workplace well-being memberikan sumbangan sebesar 33,1\% terhadap kinerja guru.

Dalam proses belajar mengajar guru harusnya dapat mengoptimalkan kinerjanya agar keinginan pendidikan berstandar nasional dalam meningkatkan potensi dan kualitas peserta didik dimasa depan dapat tercapai dengan baik maka itu workplace well-being guru terlebih dahulu diperhatikan karena faktor tersebut berperan dalam bentuk presepsi guru terhadap peker-jaannya yang sedang dijalani dan presepsi guru terhadap tempat kerjanya.

Dari kondisi guru diketahui bahwa 32 guru memiliki workplace well-being dan kinerja guru yang rendah sedangkan hanya 19 orang yang memiliki workplace well-being dan kinerja guru yang tinggi. Menurut Bahri (2011) kinerja setiap guru berbeda-beda, perbedaan tersebut dikarenakan adanya karakteristik pada masing-masing guru, jika guru ingin berprestasi akan meningkatkan kinerja yang optimal dan sebaliknya, hal tersebut didukung oleh Warr (2009) yang mengatakan memperbaiki workplace well-being akan memberikan dampak. yang positif bagi performa guru dalam sekolah secara keseluruh. Maka hipotesis yang menyatakan bahwa terdapat pengaruh yang signifikan antara workplace wellbeing terhadap kinerja guru SD.

Persamaan regresi di atas merupakan persamaan regresi positif, sehingga dapat diketahui jika nilai workplace well-being meningkat maka akan terjadi kenaikan pada kinerja guru dan sebaliknya. Sehingga dapat diketahui bahwa faktor workplace well-being merupakan faktor yang sangat penting dalam upaya meningkatkan kinerja guru SD.

Maka dapat ditarik kesimpulan hipotesis yang menyatakan terdapat pengaruh yang signifikan antara workplace well-being terhadap kinerja guru SD.

\section{Kesimpulan}

Penelitian ini mengkaji pengaruh workplace well-being terhadap kinerja guru SD. Berdasarkan hasil penelitian, terdapat pengaruh yang signifikan antara workplace well-being terhadap kinerja guru SD dengan korelasi yang negatif. Dapat dikatakan bahwa workplace well-being dalam penelitian ini termasuk ke dalam kategori rendah. Pengaruh workplace well-being terhadap kinerja guru sebesar $33,1 \%$ sedangkan $66,9 \%$ kinerja guru dipengaruhi oleh variabel lain selain workplace well-being.

\section{Daftar Pustaka}

Ariyana, M., Muzdalifah, F., Rangkuti, A.A., Wahyuni, L.D., Apsari, I.I. (2016). Panduan Penulisan SKRIPSI. Jakarta: Universitas Negeri Jakarta.

Agustin, E. (2015). Pengaruh Motivasi Kerja Terhadap Kinerja Guru Sekolah Dasar Dabin IV Kecamatan Kajen Kabupaten Pekalongan. (Skripsi). Universitas Negeri Semarang. 
Bahri, S. (2011). Faktor yang Mempengaruhi Kinerja Guru SD di Dataran Tinggimoncong Kabupaten Gowa Provinsi Sulawesi Selatan. Jurnal MEDTEK, 3(2).

Danna, K., \& Griffin, Ricky W. (1999). Health and Well-Being In The Workplace: A Review And Synthesis Of The Literature. Journal Of Management, 3(25): 357-384.

Depdiknas. (2010). Panduan Pengembangan Pembelajaran. Jakarta: Pusat Kurikulum Balitbang Diknas.

Depdiknas. (2008). Penilaian Kinerja Guru. Jakarta: Ditjen PMPTK Depdiknas RI.

Hasanah, D., Sofia. (2010). Pengaruh Pendidikan Latihan (Diklat) Kepemimpinan Guru dan Iklim Kerja terhadap Kinerja Guru Sekolah Dasar se-Kecamatan Babakancikao Kabupaten Purwakarta. Jurnal Penelitian Pendidikan, 2(11), 1-4.

Hidayah, H. (2012). Pengaruh Kompetensi Profesional Guru, Motivasi Kerja dan Disiplin Keras Terhadap Kinerja Guru Otomotif SMK Negeri Se-Kabupaten Selatan. (Skripsi). Universitas negeri Yogyakarta.

Jaedun, A. (2009). Evaluasi Kinerja Profesional Guru. In: Puslit Dikdasmen, Lemit UNY, Refleksi Profesi Guru Bersertifikassi Profesional, DIKPORA Kabupaten Cilacap, 1-2.

Kinerja Guru Rendah. (2009, Oktober 7). Kompas. Retrieved from http://nasional. kompas.com/read/2009/10/07/02424962/t witter.com

Liana, Y. (2012). Iklim Organisasi dan Motivasi Berprestasi terhadap Kepuasan Kerja dan Kinerja Guru. Jurnal Manajemen dan Akuntansi, 2(1).
Mangkungara, A.P. (2007). Manajemen Sumber Daya Manusia Perusahaan. (Ed.). Bandung: PT. Remaja Rosdakarya.

Page, K. (2005). Subjective Well-Being in The Workplace. (Thesis). School of Psychology Faculty of Health and Behavioural Sciences Deakin University.

Page, K.M., \& Vella-Brodrick, D.A. (2009). The 'What', 'Why', and 'How' of Employee well-being; A New Model. Soc Indic Res, 90: 441-458.

Ping, C.S. (2014). Pegaruh Kesejahteraan di Tempat Kerja Sebagai Pengantar Terhadap Hubungan antara Kepimpinan Trasformasi Pengetua dan Budaya dengan Penambahbaikan Organisasi Sekolah Utama Semenanjung Malaysia. (Tesis). Univertisi Sains Malaysia.

Rangkuti, A.A. (2012). Konsep dan Teknik Analisis Data Penelitian Kuantitatif Bidang Psikologi dan Pendidikan. Jakarta: FPPsi.

Sangadji, E.M., \& Sopiah. (2010). Metodologi Penelitian: Pendekaan Praktis. dalam Penelitian. Yogyakarta: Penerbit ANDI.

Simanjuntak, P.J. (2005). Manajemen dan Evaluasi Kinerja. Jakarta: FE UI.

Siregar, S. (2013). Statistik Parametrik untuk Penelitian Kuantitatif. Jakarta: PT. Bumi Aksara.

Sugiyono. (2008). Metode Penelitian Kuantitatif, Kualitatif, dan R\&D. Bandung: Alfabeta.

Undang-Undang Nomor 14 Tahun 2005, tentang Guru dan Dosen. Mendiknas RI, Jakarta. Diakses dari http://www.sjdih.depkeu. go.id/fullText/2005/14TAHUN2005UU.ht $m$ 